\title{
Editorial
}

\section{Zika Virus in Bangladesh}

\author{
MY Ali
}

Zika virus is a mosquito born - flavivirus. It is a RNA virus and closely related to other flavivirus such as dengue virus, yellow fever virus etc. It produces an infectious disease known as Zika fever or Zika virus disease or simply Zika.

Transmission: Is via the bite of mosquitoes from the Aedes genus, primarily Aedes aegypti but other member of Aedes genus may be also responsible for transmission. Sexual transmission can also occur. This virus is isolated from semen of infected person. Vertical transmission is also possible. The CDC recommends that women with Zika fever should wait at least 8 weeks at they start having symptoms of disease before attempting to conceive. Virus has been isolated in breast milk but no reported case of transmission through breast feeding is yet present. Like other flavivirus it can potentially be transmitted through blood transfusion.

Most people who are affected have no or few symptoms. Most common symptoms are fever, rash, conjunctivitis (red eye), muscle and joint pain and headache which are similar to Dengue fever or Chikungunya fever. Incubation period is usually 2 to 7 days. This disease lasts for few days to a week and usually mild. It has not caused any reported death during the initial infection but infection during pregnancy can cause microcephaly and other brain malformation in some babies. Infection in adult has been linked to Guillain-Barre Syndrome.

It was first isolated in Africa in 1947. The first documented outbreak among people occurred in 2007 in the Federated States of Micronesia. As of January 2016, the disease was occurring in twenty regions of the Americas. It is also known to occur in Africa, Asia and the Pacific. Due to an outbreak which I started in Brazilin 2015, the World Health Organization declared it a Public Health Emergency of international concern in February 2016.

Diagnosis is done by testing the blood, urine and saliva for the presence Zika virus RNA when the person is sick. It should be done within 2 to 7 days.

Treatment is symptomatic. Only paracetamol tablet and sufficient intake of fluid is necessary. NSAID, specially aspirin should not be given. But pregnancy related complications and in adult Guillain-Barre syndrome related problems can't be still prevented or treated. No vaccine is available till today. For all these reasons it's an alarming disease for human being.

1. Dr. Md. Yusuf Ali, MBBS, FCPS (Medicine), Professor \& Head, Department of Medicine, Faridpur Medical College, Faridpur.

Address of correspondence :

Dr. Md. Yusuf Ali, MBBS, FCPS (Medicine), Professor \& Head, Department of Medicine, Faridpur Medical College, Faridpur.

Phone: +88-01711425121, E-mail: mdyusufali1958@gmail.com

\section{Zika virus infection in Bangladesh:}

Bangladesh confirms its first case of Zika virus infection on March 2016 in an old sample of blood from a 60 years Old man living in southeastern port city of Chittagong. Ten Bangladeshi people become infected with Zika virus in Singapore with mild clinical features reported on $30^{\text {th }}$ August, 2016 by the Ministry of Health in Singapore.

Risk of transmission of this disease in our country is present for the following reasons; Active case has to come here for its spread in Bangladesh is present.

1. The virus is transmitted through Aedes mosquitoes and its reproduction time is in rainy season, which is present now in Bangladesh. 2. Its large population. 3. India, Philippine, Indonesia, Vietnam and Pakistan are nearer to Bangladesh are very much vulnerable for transmission of this disease. 4. Surveillance and testing system to detect the disease is lacking behind the developed countries.

So prevention is the only way to protect ourselves, which involve spreventing mosquito bite by using insects repellent, covering body with clothing, using mosquito net and getting rid of standing water where mosquito reproduce. Women in areas affected by Zika outbreak consider putting off pregnancy and that pregnant women should not travel to this areas.

\section{References :}

1. "Zika virus". World Health Organization. January 2016. Retrieved 3 February 2016.

2. "Factsheet for health professionals. Zika virus infection.European Centre for Disease Prevention and Control. Retrieved 22 December 2015.

3. Chan LH, Hammer DH. Zika virus: Rapid spread in the western hemisphere. Ann Intern Med. 2016; 164(9): 613-5.

4. Dupont-Rouzeyrol M, Biron A, O'Connor O, Huguon E, Descloux. Infectious Zika virus particles in breastmilk. The Lancet 2016; 387(10023): 1051.

5. "FDA advises testing for Zika virus in all donated blood and blood components in the US". August 26, 2016.

6. Zika virus Microcephaly and Guillain-Barre Syndrome Situation Reports" (PDF). World Health Organization. 7 April. 2016. Retrieved 8 April 2016. 